\title{
KOMUNIKASI INTERPERSONAL DALAM KEGIATAN BELAJAR MENGAJAR ANTARA GURU DAN MURID PAUD JOYCE BANJARBARU
}

\author{
Nurhayati ${ }^{1)}$ \\ Universitas Islam Kalimantan Muhammad Arsyad Al-Banjari Banjarmasin \\ Email: nong.nurhayati4124@gmail.com
}

\begin{abstract}
ABSTRAK
Latar belakang dari penelitian ini bagaimana terjalinya komunikasi interpersonal dalam kegiatan belajar mengajar antara guru dan murid untuk membangun karakter anak. Komunikasi interpersonal diterapkan dalam proses belajar mengajar juga di gunakan sebagai pendalaman karakter dari masing-masing murid. Dalam sebuah kelas, akan mempermudah proses transfer informasi antara masing-masing anggotanya sehingga guru akan lebih mudah memahami dan mendalami karakter murid untuk kemudian mengembangkan potensi yang dimiliki murid dan mengarahkan ke arah yang lebih baik. Proses komunikasi Interpersonal tidak hanya terjadi pada guru dengan murid, namun juga terjadi antara murid satu dengan murid lainnya. Rumusan masalah bagaimana komunikasi interpersonal dalam kegiatan belajar mengajar antara guru dan murid PAUD JOYCE BANJARBARU pada pembentukkan karakter anak? Bagaimana strategi komunikasi interpersonal dalam belajar mengajar antara guru dan murid pada pembentukan karakter anak? Bagaimanakah hambatan yang dihadapi untuk membentuk karakter anak menjadi anak yang cerdas,aktif dan komunikatif? Metode penelitian yang digunakan ialah penelitian kualitatif, dan objeknya para guru-guru dan orang tua. Komunikasi interpersonal di terapkan dalam proses belajar mengajar sebagai pendalaman karakter anak kemudian mengembangkan potensi yang dimiliki murid. Strategi yang dilakukan ialah menanamkan kemandirian. Hambatan yang dihadapi ialah pada faktor lingkungan yang membawa kepada unsur negatif dan yang kedua orang tua.
\end{abstract}

Kata kunci: Komunikasi Interpersonal;PAUD JOYCE Banjarbaru.

\section{PENDAHULUAN}

Manusia adalah sebagai makhluk sosial tidak akan pernah bisa melepas dari proses komunikasi, banyak sekali cara-cara yang dilakukan oleh manusia dalam proses berkomunikasi. Mereka biasa menggunakan kata maupun gerakkan dan kemudian diinterprestasikan sesuai makna yang sudah disepakati bersama, komunikasi sudah lama ada, bahkan saat dimulainya peradaban manusia.

Komunikasi mempunyai dua sifat umum, ialah langsung dan tidak langsung. Komunikasi bisa terjadi pada siapa saja dan kapan saja, baik antar guru dengan muridnya dan lain sebagainya.

Pada usia emas adalah masa yang penting dalam proses kecerdasan anak. Dalam usia 0-5 tahun, anak diajukan berbagai macam pendidikan dasar, mulai dari berbicara, bersikap, bermain, hingga diajarkan untuk bealajar pelajaran-pelajaran ringan.

Dalam membimbing anak-anak terutama anak usia dini sangat diperlukan kemampuan untuk mengembangkan komunikasi yang efektif, pendidikan yang hendak diajarkan atau diterapkan terhadap anak dapat tercapai. Tentunya harus dihindari terjadi kesalah pahaman antara anak akibat komunikasi yang tidak efektif.

Pendidikan Anak Usia Dini (PAUD) yaitu jenjang pendidikan sebelum jenjang pendidikan dasar yang merupakan suatu upaya pembinaan yang ditunjukkan bagi anak sejak lahir sampai usia lima tahun yang dilakukan melalui pemberian rangsangan pendidikan untuk membantu perubahan dan perkembangan jasmani dan rohani agar anak memiliki kesiapan dalam memasuki pendidikan lebih lanjut, yang diselenggarakan pada jalur formal, nonformal, dan informal.

Pendidikan Anak Usia Dini merupakan suatu bentuk penyelenggaraan pendidikan yang menitik beratkan pada peletakkan dasar ke arah pertumbuhan dan perkembangan fisik, kecerdasan, sosial emosionl bahasa dan komunikasi, sesuai dengan keunikan dan tahap-tahap perkembangan yang akan dilalui oleh anak usia dini. Sebagian besar pertumbuhan anak terjadi pada usia dibawah lima tahun. Beberapa ilmuan mengatakan bahwa setiap kepala seorang anak, terdapat 10 triliyun sel otak yang sudah siap tumbuh. Tetapi, karena satu bentakan atau perkataan yang kasar dapat membunuh lebih dari 1 milyar sel otak saat itu juga, bentakan kasar dapat mempengaruhi perkembanggan sel otak anak.

Dampak dari kerusakkan pada sel-sel otak karena bentakan lebih besar pengaruhnya terhadap anak-anak. Bentakan dapat berakibat buruk pada organ-organ penting seperti jantung denyut nadi manusia berubah-rubah sesuai suara yang sedang mereka dengarkan.

Tunjukkan mimik muka dan gerakan tubuh yang membuat hati anak senang dan nyaman, seperti dengan tersenyum saat mengajak mereka berbicara, menyentuh atau mengusap rambut anak, dan sebagainya. Saat berkomunikasi dengan anak, sebaiknya kita melihat anak agar anak merasakan bahwa apa yang kita sampaikan adalah sungguhsungguh. Gunakan kalimat sederhana atau mudah dipahami oleh anak. Ajukan pertanyaan terbuka dan merangsang anak untuk berfikir atau menemukan jawabannya sendiri. 
MUTAKALLIMIN; Jurnal Ilmu Komunikasi

Vol 3 No 1 Mei 2020

Dengarkan dengan penuh perhatian ketika anak menyampaikan sesuatu. Dengarkan sampai selesai dan hindari memotong pembicaraannya lalu beri tanggapan yang benar. Pada dasarnya PAUD adalah wadah bagi balita untuk mengasah dan memupuk jiwa sosial. Namun, tak hanya dalam proses tersebut balita sangat rentan berprilaku tidak baik bahkan menyimpang. Itulah hal yang wajar dialami balita dan meniru suatu hal dalam sebuah proses sosial yang lumrah terjadi.

Balita dengan mudah menirukan dari sebagian mereka lakukan, tanpa berfikir baik dan buruknya perbuatan tersebut. Karakter adalah suatu keunikan, temperemen, karakteristik atau budi pekerti membuat seseorang berbeda dari yang lain. Karakter anak dibangun dan dibentuk sejak masih usia dini oleh orang tua atau keluarga dan sekolah.

Pembentukan karakter anak dipengaruhi oleh dua faktor, yaitu faktor dalam diri anak yang bersangkutan dan faktor lingkungan. Faktor pribadi diri anak yang bersangkutan biasanya mencangkup nilainilai dan macam-macam norma yang ditanam oleh keluarga dalam hal ini ayah dan ibu. Faktor lingkungan yang bersangkutan terhadap lingkungan sekitar.

Komunikasi interpersonal diterapkan dalam proses belajar mengajar juga digunakan sebagai pendalaman karakter dari masing-masing murid. Dalam sebuah kelas, akan mempermudah proses transfer informasi antara masing-masing anggotanya sehingga guru akan lebih mudah memahami dan mendalami karakter murid untuk kemudian mengembangkan potensi yang dimiliki murid dan mengarahkan ke arah yang lebih baik.

Proses komunikasi interpersonal tidak hanya terjadi antara guru dengan murid, namun juga terjadi antara murid satu dengan murid yang lainnya. Dengan terciptanya komunikasi interpersonal maka antara murid dengan murid lainnya akan dapat mengenal dan mengetahui satu sama lain sehinga tercipta interaksi yang baik.

Dalam undang-undang tentang sistem pendidikan nasional dinyatakan bahwa pendidikan anak usia dini (PAUD) adalah suatu upaya pembinaan yang ditunjukan pada anak sejak lahir sampai dengan usia lima tahun yang dilakukan melalui pemberian rangsangan pendidikan untuk membantu pertumbuhan dan perkembangan jasmani dan rohani agar anak memiliki kesiapan dalam memasuki pendidikan lebih lanjut (UU Nomor 20 Tahun 2003 (Undang-undang Sistem Pendidikan Nasional)) Bab 1 Pasal 1 Ayat 14). Dalam pasal 28 ayat 3 Undang-undang Sistem Pendidikan Nasional dinyatakan bahwa pendidikan anak usia dini pada jalur pendidikan formal berbentuk Taman Kanak-kanak (TK) atau bentuk lain yang sederajat.

Satuan pendidikan anak usia dini merupakan institusi pendidikan anak usia dini yang memberikan layanan pendidikan bagi anak usia lahir sampai dengan 5 tahun.

a) Taman Kanak-kanak (TK)
TK merupakan suatu bentuk satuan pendidikan bagi anak usia dini pada jalur pendidikan formal yang menyelenggarakan pendidikan bagi anak usia 4 sampai 6 tahun, yang terbagi menjadi 2 kelompok: kelopok A untuk anak usia 4-5 tahun dan kelompok B untuk anak usia 5-6 tahun.

b) Kelompok Bermain (play group)

"Kelompok bermain salah satu bentuk pendidikan anak usia dini pada jalur pendidikan nonformal yang menyelenggarakan program pendidikan sekaligus program kesejahteraan bagi anak usia 2 sampai dengan 4 tahun". ( Yuliani Nurani Sujiono, 2009: 23)

c) Taman Penitipan Anak (TPA)

Taman penitipan anak merupakan salah satu bentuk pendidikan anak usia dini pada jalur pendidikan nonformal yang menyelenggarakan program pendidikan sekaligus pengasuhan dan kesahteraan anak sejak lahir. TPA sebagai pendidikan dan pembinaan kesejahteraan anak yang berfungsi sebagai pengganti keluarga untuk jangka waktu tertentu selama orang tuanya berhalangan atau tidak memiliki waktu yang cukup dalam mengasuh anaknya karena berkerja atau sebab lain. (Yuliani Nurani Sujiono, 2009: 24)

Landasan Pendidikan Anak Usia Dini Dalam Amandemen UUD 1945 pasal 28 B ayat 2 dinyatakan bahwa : Setiap anak berhak atas kelangsungan hidup, tumbuh dan berkembang serta berhak atas perlindugan dari kekerasan dan diskriminasi.

Dalam UU No. 20 Tahun 2003 tentang sistem pendidikan nasional Bab 1, pasal 1, butir 14 dinyatakan bahwa : Pendidikan anak usia dini adalah suatu upaya pembinaan yang ditunjukkan kepada anak sejak lahir sampai dengan usia 6 tahun yang dilakukan melalui pemberikan rangsangan pendidikan untuk membantu pertumbuhan dan perkembangan jasmani dan rohani agar anak memiliki kesiapan dalam memasuki pendidikan lebih lanjut.

Kemudian pada pasal 28 tentang pendidikan anak usia dini dinyatakan bahwa:

1) Pendidikan anak usia dini diselenggarakan sebelum jenjang pendidikan dasar.

2) Pendidikan anak usia dini dapat diselenggarakan melalui jalur pendidikan formal, nonformal, dan informal

3) Pendidikan anak usia dini jalur pendidikan formal: TK, atau bentuk lain yang sederajat.

4) Pendidikan anak usia dini jalur pendidikan nonformal: KB,TPA, atau bentuk lainnya yang sederajat.

5) Pendidikan usia dini jalur pendidikan informal: pendidikan keluarga atau pendidikan yang diselenggarakan oleh lingkungan.

6) Ketentuan mengenai pendidikan anak usia dini yang diatur oleh peraturan pemerintah.

\section{Rumusan Masalah}

Berdasarkan latar belakang masalah yang diuraikan diatas maka rumusan masalah yang dikemukakan adalah sebagai berikut : 
1. Bagaimana komunikasi interpersonal dalam kegiatan belajar mengajar antara guru dan murid PAUD JOYCE BANJARBARU pada pembentukkan karakter anak

2. Bagaimana strategi komunikasi interpersonal dalam belajar mengajar antara guru dan murid PAUD JOYCE BANJARBARU pada pembentukkan karakter anak

3. Bagaimanakah hambatan yang dihadapi PAUD JOYCE BANJARBARU untuk membentuk karakter anak menjadi anak yang cerdas,aktif dan komunikatif

\section{Fokus Penelitian}

Fokus masalah dalam penelitian ini yaitu hanya membahas bagaimana komunikasi interpersonal diterapkan dalam proses belajar mengajar digunakan untuk pendalaman karakter anak dan bagaimana berkomunikasi dengan baik terhadap anak.

\section{Tujuan Penelitian}

Adapun tujuan dilakukanya penelitian ini adalah untuk :

1. Mengetahui strategi komunikasi interpersonal dalam kegiatan mengajar dan belajar antara guru dan murid PAUD JOYCE BANJARBARU pada pembentukkan karakter anak

2. Komunikasi interpersonal apa saja yang dilakukan dalam kegiatan belajar mengajar PAUD JOYCE BANJARBARU pada pembentukkan karakter anak

3. Hambatan apa saja yang dihadapi PAUD JOYCE BANJARBARU pada pembentukkan karakter anak

\section{Kegunaan Penelitian}

Hasil dari penelitian ini diharapkan akan dapat berguna dan memberi manfaat untuk menambah wawasan peneliti, memberikan masukan erhadap perkembangan ilmu komunikasi khususnya dalam mengetahui strategi komunikasi dalam proses belajar mengajar dan pola komunikasi antara guru dan murid yang digunakan PAUD JOYCE BANJARBARU.

\section{METODE PENELITIAN}

Penelitian yang digunkan dalam penelitian ini, penelitian kualitatif. Dipilihnya metode penelitian kualitatif ini agar peneliti bisa memahami dan menggambarkan bagaimana fenomena yang sedang terjadi pada penelitian secara aktual mengenal apa saja strategi yang dilakukan oleh PAUD JOYCE. Metode kualitatif digunakan sebagai meramu secara ilmiah sebagai informasi. Metde kualitatif suatu penelitian ilmiah yang bertujuan untuk memahami suatu fenomena dalam kontek sosial secara alamiah dengan mendapatkan proses interaksi komunikasi yang mendalam antara peneliti dengan fenomena yang diteliti. Peneliti melakukan wawancara kepada Guru Kelas dan Orang Tua Murid. Teknik untuk pengumpulan data yaitu dengan Observasi, Wawancara, dan Dokumentasi.

\section{HASIL PENELITIAN}

Setelah melakukan wawancara dengan narasumber, peneliti mencoba menganalisis berdasarkan data-data yang telah didapat melalui wawancara dengan Guru kelas dan Orang tua murid. PAUD JOYCE BANJARBARU merupakan sekolahan swasta yang beralamtkan dijalan Pangeran Suriansyah No.17 Rt.01/Rw.05, Kelurahan.Mentaos Kecamatan.Banjarbaru Utara, Kota Banjarbaru. PAUD TERPADU JOYCE BANJARBARU menggunakan program yang berdasarkan dari DIKNAS dengan penerapan dan pengembangan yang mengacu pada bidang bahasa, kognitif, seni, sosial-emosional, nilai moral dan agama diwujudkan dalam satuan kegiatan pertema dilaksanakan dalam bentuk satuan kegiatan harian dengan hari sebagai berikut: Playgroup pada hari Senin- Jum'at dari jam 08: 00 WIB- 10: 30 WIB, sedangkan untuk TK hari Senin- Kamis dari jam 08: 00 WIB- 11: 30, dan untuk hari Jum'at- Sabtu dari jam 08: 00- 10: 30. Disamping itu untuk meningkatkan kualitas dan kemampuan murid juga sebagai penyaluran hobi, kami adakan kegiatan ekstra kurikuler (iqra, dance, modelling, drumban, komputer, yoga). Sedangkan untuk kegiatan lainnya di luar kelas yaitu (outdor, kids kamp, cooking class). Dalam melakukan belajar mengajar memerlukan beberapa strategi dan komunikasi interpersonal untuk memahami dan mengembangkan karakter anak.

Strategi dalam membentuk karakter anak adalah dimulai dengan mengajarkan kedisiplinan pada si kecil. Anak yang memiliki kedisiplinan diri dapat mengatasi perasaan emosi yang tidak nyaman pada dirinya dengan cara yang sehat. Tidak hanya itu saja, mengajarkan kedisiplinan pada si kecil juga mampu memberikan manfaat.

Seorang guru diharapkan mampu menjalin komunikasi dan intraksi yang baik dengan anak didiknya, agar tercipta keselarasan dalam proses belajar. Guru harus aktif membimbing anak didiknya agar dapat membentuk pribadi yang baik. Guru harus mampu menangkap respon balik dari murid, baik respon verbal dan nonverbal. Kemampuan berkomunikasi tidak terbatas pada pandai tidaknya berbicara, terjalinnya komuniasi yang baik antara guru dan murid akan berlangsung baik dan optimal.

Strategi yang dilakukan guru dalam membentuk karakter anak adalah dimulai dengan mengajarkan kedisiplinan pada murid selain itu guru diharapkan mampu menjalin komunikasi dan intraksi yang baik terhadap murid.

Strategi yang dilakukan guru melalui kegiatan proses belajar mengajar berpedoman pada kurikulum 13 yang berbasis kopetensi dan berbasis karate yaitu yang memiliki 4 aspek penilaian yaitu aspek pengetahuan, keterampilan, sikap dan prilaku. Komunikasi interpersonal yang dilakukan guru dalam belajar mengajar adalah guru selalu bertanya terhadap anak dan ketika anak berceloteh dan bercerita guru harus mendengarkanya dan berikan tanggapan kepadnya. Komunikasi interpersonal dalam kegiatan 
belajar mengajar guru dan murid untuk membentuk karakter anak adalah biasanya dilakukan setiap saat pada kegiatan pembelajaran karena kegiatan pembelajaran berlangsung dengan cara bermain sambil belajar jadi setiap kegiatan guru bisa menyelipkan pendidikan karakter didalamnya dengan prilaku seharihari.

Hambatan yang dihadapi adalah pada faktor lingkungan kadang mudah diatur jika dilingkungan sekolah ia akan menurut apa perintah guru namun jika dirumah mereka lebih susah diatur dikarnakan orang tua yang lebih memanjakan. Hambatan yang dihadapi adalah kurang kerja samanya antara guru dan orang murid. Meskipun pihak sekolah sudah memprogramkan dan merencanakan dengan baik. Namun karena kurangnya pemahaman orang tua maka program tersebut sulit terwujud secara maksimal. Hambatan lain yang dialami yaitu pendidikan karakter melalui komunikasi verbal dimana sebagian anak usia dini masih terbatas cara menerima dan mengungkapkan bahasa dikarenakan keterlambatan bicara atau anak berkebutuhan khusus.

\section{KESIMPULAN}

Berdasarkan hasil dari penelitian yang telah didapatkan dari penelitian dapat disimpulkan sebagai berikut:

1. Komunikasi interpersonal dalam kegiatan belajar mengajar antara guru dan murid pada pembentukan karakter pada murid ialah diterapkan dalam proses belajar mengajar digunakan sebagai pendalaman karakter dari masing-masing murid. Dalam sebuah kelas, akan mempermudah proses transfer informasi antara masing-masing murid sehingga guru akan lebih mudah memahami dan mendalami karakter murid untuk kemudian mengembangkan potensi yang dimiliki murid mengarahkan kearah yang lebih baik lagi.

2. Strategi yang dilakukan guru dalam belajar mengajar antara guru dan murid ialah kembali kepada guru sebagaimana telah memberikan contoh yang nyata terhadap murid dalam melakukan segala hal seperti membuang sampah pada tempatnya, menanamkan kedisiplinan, sopan dan santun, memberikan pujian terhadap murid karena dia telah berhasil melakukan apa yang telah di ajarkan oleh guru agar membangun semangat murid.

3. Hambatan yang dihadapi untuk membentuk karakter anak menjadi anak yang cerdas, aktif dan komunikatif ialah pada faktor lingkungan yang membawa kepada unsur negatif seperti susahnya untuk menaati peraturan dikelas, kurangnya bersosialisasi terhadap teman dan lingkungan. Dengan kurangnya bersosialisasi membuat anak susah untuk berkomunikasi dengan teman atau pun orang disekitar terutama untuk ke egoannya lebih tinggi contohnya anak akan terlihat susah untuk berbagi dengan teman. Karena itu selain seringnya terjalin komunikasi terhadap murid dan guru perlu juga terjalinya komunikasi antara guru dan orang tua untuk kerja samanya dalam menanamkan sifat karakter pada anak.

Guru menyampaikan pesan baik verbal atau nonverbal, murid menerima bereaksi dengan memberi jawaban verbal atau nonverbal, begitu pula sebaliknya.

\section{SARAN}

Berdasarkan dari hasil penelitian, maka penulis merekomendasikan berupa saran-saran sebagai berikut:

1. Guru harus selalu meningkatkan komunikasi interpersonal terhadap semua anak jangan sampai ada merasa memperoleh perlakuan yang berbeda dari guru.

2. Salah satu strategi yang dilakukan guru yaitu harus ada penambahan jumlah mainan bagi anak-anak PAUD JOYCE BANJARBARU untuk mengatasi hambatan yang terjadi dalam proses belajar, selain itu juga akan meningkatkan semangat dan minat belajar anak khususnya dalam metode bermain.

3. Guru PAUD JOYCE BANJARBARU harus meningkatkan terjalinnya kerja sama dan kemampuan berpengetahuan, pengalman, pemahaman dan kreatif dalam kegiatan belajar mengajar agar murid lebih bergairah dan bersemangat dalam belajar, jangan lupa untuk selalu bersabar.

Demikian saran dari penulis semoga dengan ditulisnya sekripsi ini bisa bermanfaat bagi semua secara khususnya bagi penulis.

\section{REFERENSI}

\section{Buku}

Alo Liliweri, 2011 Komunikasi Serba Ada Serba Makna. Edisi pertama. Prenada

Media. Kencana: Jakarta.

Budyatna Muhammad dan Leila Mona Ganiem, 2011 Teori Komunikasi Antar

Pribadi. Kencana: Jakarta.

Deddy Mulyana, 2001 Ilmu Komunikasi Suatu Pengantar. Divisi buku umum, Remaja Rosada Karya: Bandung.

Effendy, 2004. Ilmu Teori dan Filsafat Komunikasi. Remaja Rosda Karya: Bandung.

Effendy, Onong Uchjana, 2003. Ilmu Komunikasi dan praktek. PT Remaja Rosdakarya: Bandung

Sardiman, 2007 Intraksi dan Motivasi Belajar Mengajar. PT. Raja Grafindo

Persada: Jakarta.

Sunarto, 2003 Komunikasi Antar Pribadi.Gramedia Pustaka Jaya: Jakarta.

Tommy Suprapto, 2006 Pengantar Teori Komunikasi. Media Pressindo: Yogyakara. 
MUTAKALLIMIN; Jurnal Ilmu Komunikasi

Vol 3 No 1 Mei 2020

Yuliani Nurani Sujiono, 2004 Konsep Dasar Pendidikan Anak Usia Dini Indeks: Jakarta

\section{Skripsi}

Ahmad INTERPERSONAL ANTARA

PIMPINAN DAN STAF (Studi Deskriftif Kualitatif Pola Interaksi Antara Pemimpin Dan Staf Sekretariatan Dinas Komisi Pelayanan Indonesia Daerah (KPID) Provinsi Jawa Tengah). Fakultas Ilmu KomunikasiUniversitas Muhammadiyah, Surakarta.

Herdiansyah Pratama. 2011. POLA HUBUNGAN KOMUNIKASI INTERPERSONAL ANTARA ORANG TUA DENGAN ANAK TERHADAP MOTIVASI BERPRESTASI PADA ANAK. Fakultas Ilmu KomunikasiUniversitas Islam Negeri Syarif Hidayatullah, Jakarta.

Usin Khoirul Anisah. 2011. ANALISIS DESKRIPTIF KOMUNIKASI INTERPERSONAL DALAM KEGIATAN BELAJAR MENGAJAR ANTARA GURU DAN MURID PAUD ANAK PRIMA PADA PROSES PEMBENTUKAN KARAKTER ANAK (Studi deskripsi komunikasi interpersonal antara guru dan murid yang diterapkan PAUD anak prima dalam rangka mencapai tujuan pendidikan bagi balita). Fakultas Ilmu Komunikasi Universitas Pembangunan Nasional "Veteran" Yogyakarta.

(Kasus Pantai Parangtritis Dan Sekitarnya). Jurnal Teknologi Lingkungan Volume 2, Nomor 2, Mei. Halaman 159-167.

Wisyanto. 2003. Analisis Potensi Bahaya Tsunami Di Pantai Selatan Jawa Timur Melalui Identifikasi Kemiripan Bentuk Tapchan. Jurnal Alami, Volume 8, Nomor 2. Halaman 33-38. 